\title{
'There Can Be No Revolution without Culture': Reading and Writing in the Bolivarian Revolution
}

\author{
KATIE BROWN
}

University of Bristol

\begin{abstract}
Under Hugo Chávez's 'Bolivarian Revolution', the government made itself present in all stages of literary production, applying the official idea of reading and writing as 'socialist practices'. The Bolivarian government envisaged a popular counter-hegemony, courting popular support while delegitimising cultural elites and reinforcing class tensions. Bolivarian cultural policy is anachronistic in an age of global literary markets, while the emphasis on a national collective of writers over internationally promoted representative writers of the revolution is particularly radical.
\end{abstract}

Keywords: Bolivarian Revolution, counter-hegemony, reading, populism, publishing, Venezuela.

A revolution that is not accompanied by a cultural drive intended to give power back to our roots, push our ideas and rescue our customs and everything else that culture implies.... That's not a revolution! It's like a rocket without fuel. - Hugo Chávez Frías

The above declaration by Hugo Chávez, President of Venezuela from 1999 to 2013, launched Misión Cultura, one of the Bolivarian government's wide-ranging plans for popular mobilisation, designed to inculcate revolutionary values through cultural participation (Ministerio de comunicación..., 2005). More well-known missions include Robinson, Sucre and Ribas (education), Barrio Adentro (community healthcare) and Mercal (food distribution) (España, 2008; Hawkins, Rosas and Johnson, 2011). That there could be no revolution without culture was a statement made repeatedly by Chávez throughout his presidency (TeleSUR, 2013), yet little attention has so far been paid to Bolivarian cultural policy 
(Bermúdez and Sánchez, 2009; Afanador et al, 2011). While Misión Cultura covered everything from music to sport, this article focuses on reading and writing. It complements work by Michelle Farrell (2011) on film and by Victoria Rodner (2014) on the art market. Although the Bolivarian Revolution continues in power under President Nicolás Maduro, his presidency has been marked by falling oil prices, shortages and increasingly violent protest, leading to different priorities and policies. While some cultural policy remains the same, other schemes have been abandoned, and Maduro brought in his own Law of Culture in 2013. For these reasons, this article only considers developments during Chávez's 14-year presidency.

This article will demonstrate how revolutionary ideology permeated governmental rhetoric, policy and practice related to all stages of production and consumption of books in Venezuela, suggesting that the policies and practices implemented by the Bolivarian government were designed to win or cement popular support. The aim of this article is not to discredit the democratising objectives of the Bolivarian Revolution nor the obvious benefits of mass distribution of books and wide-scale training programmes in empowering underprivileged Venezuelans. Instead, this article demonstrates that the defining characteristics of the Bolivarian Revolution - populism (Hawkins, 2010; Corrales and Penfold, 2011), nationalism (Gott, 2000; Roberts, 2004), class polarisation (Cannon, 2008) and ongoing radicalisation (Ellner, 2011a, Williamson, 2009: 595) - have conditioned the Bolivarian government's engagement with reading and writing.. Further research is required among users of state cultural resources to judge what effect these have had, both in relation to reading and writing and in terms of support for the government.

The key to understanding Bolivarian approaches to reading and writing lies in the belief in counter-hegemony as vital for a successful revolution. Iván Padilla, Vice-Minister for Culture asserted in 2005 that 'the hegemony of the dominant and exploitative classes is confronted and defeated by the hegemony of the dominated, the exploited, the proletariat' (Kozak Rovero, 2007: 108). This conception of hegemony leaves no space for alliances or compromises with traditional elites. It is populist, following Kirk A. Hawkins's definition of populism as 'a discourse or worldview that celebrates the people's will and its unmediated expression as the ultimate repository of goodness' (Hawkins, 2010, 247). Thus, while initiatives related to reading and writing have encouraged inclusion of non-traditional actors, they demonstrate the 'deliberate exclusion of large segments of society' that Corrales and Penfold see as one of the key ways in which the Bolivarian Revolution maintains its power (Corrales and Penfold, 2011, 8; see also Hawkins, 2010, 232).

A Radical BreakHugo Chávez's landslide victory in the presidential elections of December 1998 brought an end to a forty-year period known as Punto Fijo, during which the parties Acción Democrática 
and Comité de Organización Política Electoral Independiente governed alternately. By the end of the Punto Fijo period, the democratic and economic stability that had characterised the era was crumbling and people were calling for radical change (Smilde, 2011; Silva-Ferrer, 2014, 71-90). Chávez's election promised an era of transformation in Venezuela, beginning with the new Constitution in 1999, through which the name of the country was officially changed to the Bolivarian Republic of Venezuela. When Chávez came to power, his Bolivarian government inherited the Consejo Nacional de Cultura (National Council for Culture, CONAC), which had been formed in 1975 to guarantee the right of all people to the enjoyment and creation of cultural goods and to facilitate the production, training, promotion, research, conservation and diffusion of all aspects of culture (Congreso de la República de Venezuela, 1975). However, as the counter-hegemony of the Bolivarian Revolution depends on the image of a radical break with the past, in 1999, during the process of designing a new constitution, a series of meetings and discussions known as the Great National Meeting for Culture were organised, asserting the need to legislate culture, to create a cultural ministry, and to define the country's cultural policy (Comisión Permanente de Educación..., 2005: 2). In practical terms, little changed until 21 January 2001 when, during his regular television broadcast Aló Presidente, Chávez declared a 'cultural revolution' and replaced the directors of state-run cultural institutions live on-air. The President insulted the former directors and accused them of kidnapping culture for the elite (Méndez, 2013; Silva-Ferrer, 2014: 117118). This was a striking example of the division between 'the elites' and 'the people' present throughout Bolivarian rhetoric, which builds on existing, powerful class polarisation to win popular support. Luís Britto García (2001) referred to this event as 'el Culturazo', recalling the violence, chaos and devastation of the Caracazo riots of February 1989. By replacing all the most powerful people in the Venezuelan cultural sector in this way, Chávez displayed his own position as the ultimate authority in the new Venezuela, while simultaneously ensuring that those who would take over control of state cultural institutions would be loyal to his new regime and would manage the cultural sector following the Bolivarian tenets of popular participation and instilling socialist values. This symbolic violence towards cultural elites mirrors increased radicalisation in other areas of governance in 2001 (Ellner, 2011a: 250). Although parallels can be drawn with cultural policy in the Cuban Revolution here, it is notable that Fidel Castro addressed intellectuals with respect in his famous 1961 speech, explaining rationally the idea of culture at the service of the revolution, whereas moves such as this mass firing by Chávez were deliberately antagonistic, designed to turn viewers against the established cultural elites.

From 2001 until 2005, a series of workshops, conferences and other events took place throughout the country to establish the Law of Culture (Comisión Permanente de Educación..., 2005: 2). The law, passed in 2005, outlined how culture was to be administrated by various state institutions and guaranteed state funding to all aspects of cultural creation, while at the same time establishing the values and uses 
attributed to culture by the Bolivarian government. The 'revolutionary' use of culture is enshrined in Article 10, which states that culture is a matter of public interest and a strategic priority to achieve the transformation of Venezuelan society. In 2004, the figure of Minister for Culture was created, a position first held by Francisco Sesto. While Sesto in some ways represented a continuation, having been president of CONAC at the time of his appointment, he stressed repeatedly that the Bolivarian Revolution offered a radical change. In a revealing interview entitled El pueblo es la cultura (The People are Culture), Sesto asserted that 'the book is a weapon' and 'a tool for liberation', adding 'We cannot imagine a revolution, a process of profound change, without the book playing a starring role' (Wisotzk, 2006: 39-40). Given that before this time there had been a limited reading public in Venezuela (Torres, 2006), books are not useful tools because they are already widely read, but as something new being offered to people by the government.

Sesto's appointment was followed in 2005 by the creation of the Ministry of Popular Power for Culture. As the inclusion of popular power in the name suggests, the functioning of the ministry was in line with the ideal of participative democracy, a central feature of the Bolivarian plan for Venezuela (López Maya and Lander, 2011). Sesto asserted, 'We are working in the Ministry to remove the whole bureaucratic structure of a ministry. The Ministry should be an agent, an instrument of the people as a whole. We must trust in the wisdom of the people' (Wisotzk, 2006: 14-15). He did not elaborate on how the 'wisdom of the people' would be determined, by whom, or how this would be put into practice. These comments demonstrate Nestor García Canclini's claim that populist regimes 'try to ensure that the people do not remain as the passive receiver of communicational actions' but instead think of themselves as active participants (García Canclini, 1995: 192). This is a way of legitimising rule because it affirms to people that they are recognised by and included in the national system (García Canclini, 1995: 191). In addition, Sesto's anti-bureaucracy stance reflects that held in other areas of governance. As Ellner (2011b) maintains, the absence of bureaucracy is a shortcoming of the Bolivarian Revolution, as it both leaves the system open to abuse and lacks follow-through. The ministry marked a turning point as culture became a higher priority for the government (Bermúdez and Sánchez, 2009: 555). When Chávez appointed Sesto, he said 'We are in debt to culture' (Sesto, 2006: 40), acknowledging that the Bolivarian Revolution had yet to have a substantial impact on the cultural sector. With the new ministry in place, CONAC was disbanded by official decree in 2008. Sesto insisted that CONAC had completed its purpose, as it was at the service of a conception of cultural management belonging to a period that was long over (Letralia, 2008), thereby reinforcing the idea that the new administration was a complete break from its predecessor. 


\section{State Publishing and the 'Necessary Book'}

If books - Sesto refers notably to 'the book' and not the more elite-sounding 'literature' - were to be a valuable weapon in the revolution, what should they be like? The manifesto of the Platform for Books and Reading describes 'the book as a means of communication, a resource for developing citizenship, for the emancipation of social conscience and for the preservation of the cultural patrimony of our people' (Plataforma del Libro y la Lectura, 2007). Writing and ideology are intrinsically linked here. This idea of books at the service of the revolution has been seen previously in Guatemala (1944-1954), Cuba (especially 1959-1968) and Nicaragua (1979-1990). However, the instrumentalisation of writing in Venezuela is particularly striking, as any ideas of writing as art are eschewed in favour of creating and reinforcing a national community, to which readers should be loyal. The manifesto states the Platform's aim to promote:

The Necessary Book written from the generous essence of the heroic Venezuelan people, which reinvents, grows and transforms our circumstances every day, in order to overcome the infinite challenges demanded by this historical time in favour of the construction of a homeland powered by Bolivarian socialism. (Plataforma del Libro y la Lectura, 2007)

Notably, it is the book, not the author, which is necessary. According to García Canclini, 'the dramatisation of patrimony is the effort to simulate that there is an origin, a founding substance, in relation to which we should act today' (García Canclini, 1995: 110). Accordingly, through 'the Necessary Book', the people should both recognise themselves in the nation and be encouraged to carry out their civic duty which will make them part of something great. As Casanova (2004) explores, this idea of the national as necessary is anachronistic, given that most countries have moved away from nation-building literature as they have matured politically.

Sesto calls the platform a cross-sectional plan of action (Wisotzk, 2006: 29), as it brings together all state literary institutions, from publishers and printers to promoters and booksellers. The confluence of state and government is made clear in the official statements of the Platform in which all the organisations involved affirm that their work supports the construction of Bolivarian socialism (Kozak Rovero, 2007: 104). In this way, state publishers Monte Ávila and Biblioteca Ayacucho (founded in 1968 and 1974 respectively) as well as other literary institutions created during the Punto Fijo period join forces with new institutions created by the Bolivarian government. Monte Ávila stated its commitment to the 'historical transformation of Venezuela' on its website and confirmed that it had redesigned its editorial line to face new challenges and connect with a much wider public (Monte Ávila, 2014). This new 
editorial line included three new collections: 'Mileniolibre' (Free Millennium), the 'Biblioteca del pensamiento revolucionario' (Library of Revolutionary Thought), and 'Bitácora rebelde' (Rebel Logbook). The titles of these collections again demonstrate the insistence on the Bolivarian Revolution as a radical change. Gisela Kozak Rovero describes Mileniolibre as bringing together the most hardcore figures of the international radical left and criticises the use of state funds to publish propaganda for the Bolivarian revolution (Méndez, 2013). This 'redesign' is emblematic of the attempt to replace the hegemony of the elites with a popular counter-hegemony. It replaces collections that were recognised internationally for their literary quality (Márquez Rodríguez, 1999), cultivated to secure democratic Venezuela's place in international cultural circuits following the isolation of the Pérez Jiménez dictatorship (1948-1958). The change in editorial practice demonstrates that, while large parts of Latin America are looking to the global cultural market for economic growth (García Canclini, 2002), Venezuelan officials are once again more focused on influencing national readers than international ones.

Biblioteca Ayacucho was founded by José Ramón Medina and Uruguayan cultural theorist Ángel Rama, with a specific focus on Latin American classics and non-fiction, predominately historical or political, texts. The collection, which remained very similar under the Bolivarian Revolution, exemplifies the tension between nationalist exceptionalism and seeing Venezuela as part of a wider Latin American community. There were socialist writings among the collection, but these were historical texts, often from the nineteenth century, including a compilation called Utopismo socialista (1830-1893). Biblioteca Ayacucho, therefore, has not become a vehicle for state propaganda in the same way that Monte Ávila has. However, under the Platform, the running of these formerly very separate publishing houses has been increasingly centralised.Moreover, within this system, both Monte Ávila and Biblioteca Ayacucho take a back seat to El perro y la rana [The Dog and the Frog], the new publishing house founded by the Bolivarian government.

Described as the 'true paradigm' of Bolivarian cultural policy (Kozak Rovero, 2007: 113), El perro y la rana caused the most radical change to the landscape of state publishing in Venezuela under Chávez. The publishing house says it responds to 'the need for the national government to execute the mass publication of books and magazines whose themes are in tune with public interest' (Ministerio del Poder Popular para la Cultura, 2007). It is noteworthy that they refer to the needs of the government, making their partisan nature explicit, and putting into question how they define 'public interest'. State oil revenue is used to subsidise production costs, so that their books can be sold for nominal amounts through the Librerías del Sur network. Between 2006 and 2015, El perro y la rana published over 4,700 titles by over 800 previously unpublished authors, distributing over 7,771,000 books across the country (El perro y la rana, 2015), a remarkable achievement in the democratisation of reading and writing. Nonetheless, this mass publishing scheme delegitimises writing as a profession. El perro y la rana books cost less than a 
dollar, meaning there is no recuperation of production costs. Kozak Rovero argues that this creates the idea that books published by independent publishers, without state subsidies, are bourgeois and elitist, unnecessarily expensive status symbols (Kozak Rovero, 2007: 114), thus reinforcing class polarisation. The divide between 'elitist' publishers and the new publishing house was reinforced in the name El perro y la rana, chosen, according to Sesto, because it is funny and therefore 'removes the aura of solemnity' from the book, making it less sacred and more accessible (Wisotzk, 2006: 40).

A key part of the Bolivarian strategy to democratise culture has been the Cada día un libro [A Book Every Day] collection, which was first published by CONAC in 2005 before passing to El perro y la rana when CONAC was shut down. The collection publishes books without any exclusionary criteria, so that anyone who wishes to can easily become a published author. As the presentation published on the first page of every book in the collection explains, the texts are winners of the Certamen Mayor de las Artes y las Letras, a nationwide competition that awards writing, theatre, dance and visual arts. The first competition for writing took place in 2004. 360 books would be chosen to be published, promoted and distributed, making 15 books for each state, in line with the government's aim to decentralise writing, moving away from Caracas as the centre of literary activity (Prensa-CONAC, 2005). The democratisation, or desacralising, of literature is evident in the emphasis placed on having ideas and dreams rather than any technical or stylistic qualities. The presentation text also reinforces the idea of the Bolivarian Revolution as an attack on the hegemony of the elites, declaring to readers that the government cares for them when previous governments did not. When the winners of the second writing round of the Certamen Mayor were published by El perro y la rana in 2007, the presentation became more hyperbolic and incorporated military imagery. This new presentation stresses more forcefully that a great number of Venezuelans who wanted to publish were excluded under previous governments, equates this exclusion with their subjugation to capitalist elites, and posits writing as a form of liberation. It once again places political drive and creative will over technical skill. Such hyperbolic language is designed to spark revolutionary fervour in readers, and thereby encourage continued support for the Bolivarian 'Process'. As well as the presentation texts, the cover designs for the collection show the evolution of Cada día un libro as a tool for instilling the values of the Bolivarian Revolution. The 2005 design features a block of colour (orange for fiction, red for crónicas [creative non-fiction], pink for theatre), with the name of the author and the title of the book displayed prominently as well as the logos of the Ministry for Culture and CONAC. The 2007 design, by contrast, visualises the idea that each writer is part of a collective: the cover is filled with names of authors and titles in the collection with the author and the title of that book in bold. Comparison between the 2005 and 2007 Cada día un libro collections offers an example of the ongoing radicalisation of the Bolivarian government, buoyed by successive electoral victories (Ellner, 2011a). Moreover, as 2007 was the year in which the Partido Socialista Unido de Venezuela [United 
Venezuelan Socialist Party] was formed as the official chavista party, it is unsurprising that the language and imagery used in the collection changed to reflect the rhetoric of the party. The emphasis on the collective as the voice of the nation makes the Bolivarian approach to writing more radical than that of previous revolutionary governments who promoted certain authors as representatives of the revolution, such as Luis Cardoza y Aragón in the Guatemalan Revolution (Davisson, 2013) or Ernesto Cardenal and Rosario Murillo under the Sandinistas in Nicaragua (Goldman, 1987).

\section{Literary Institutions}

In addition to publishing houses, the government controls a range of institutions,. including the Fundación Casa Nacional de Letras Andrés Bello (Andrés Bello National Literary Foundation, Casa Bello) and the Centro de Estudios Lationamericanos Rómulo Gallegos (Rómulo Gallegos Centre for Latin American Studies, CELARG). When Casa Bello was formed by Rafael Caldera in 1973, it had as its objective, honouring its namesake, to promote the study of humanism in Spanish America (Grases González, 1995: 311). Under the Bolivarian government, the foundation promotes and teaches writing among underprivileged sectors of the population through activities such as masterclasses and workshops. However, since 2006, Casa Bello has also run the annual Salvador Garmendia national prize for short story collections, which offers a cash prize and publication. The first winner of the prize, Carolina Lozada's Historias de mujeres y ciudades, was published in 2007 in a run of 1,500 copies. The prize therefore complicates the dominant narrative from critics of the Bolivarian government that there is no space or support for literary quality. It is important to remember that such support does exist but receives much less publicity and financing than programmes like Cada día un libro.

Like Casa Bello, CELARG is another Punto Fijo institution, created in 1974, which has become part of the Bolivarian government's system for culture. The centre runs workshops and prizes, as well as carrying out research, and their activity extends beyond literature to theatre and music. While it can be likened to the Cuban Casa de las Américas, CELARG neither offers support to nor is supported by leading Latin American authors, as happened with the Cuban centre. One of the biggest responsibilities of CELARG is running the Rómulo Gallegos literary prize. Founded in 1964, the prize became a symbol of the state's commitment to culture and desire to institutionalise democracy during the Punto Fijo period (Bencomo, 2006: 763). Gallegos himself symbolises the conjunction of literature and democracy in Venezuela, as in 1948 the author was elected president of the Republic, ruling for nine months until he was overthrown by a military coup. The Rómulo Gallegos Prize became one of the most prestigious and sought-after literary prizes in Latin America, with winners including Mario Vargas Llosa for La casa verde in 1967, Gabriel García Márquez for Cien años de soledad in 1972, and Carlos Fuentes for Terra 
Nostra in 1977. Despite its prestige in the Punto Fijo period, however, the prize has come under discussion during the Bolivarian period. In 2001, Roberto Bolaño, criticised the running of the prize. He recounted that the 'neo-Stalinists' never asked for his opinion despite listing him as a judge and affirmed that he had nothing to do with the jury (Bolaño, 2001). Ignoring these comments, socialist magazine Apporea later claimed Bolaño was unable to complete his role on the jury due to his kidney failure (Azócar, 2013). A polemic also erupted in the pages of El País in 2005, as Gustavo Guerrero (2005) claimed that Spanish author Isaac Rosa had won the prize that year as reward for his support of Castro and Chávez given the political position of the jury members, a claim Rosa (2005), as well as critic Andrés Pau (2005), promptly refuted. What emerges from these debates is that, regardless of whether juries are making decisions based on politics or not, it has become impossible to separate the literary field from politics in public opinion.

To help the people realise their writing potential, both Casa Bello and CELARG offered a variety of programmes designed to broaden popular participation significantly. Casa Bello's activities served as a supplement to traditional education, and included running programmes or one-off events in schools, prisons and local communities, as well as ongoing writing workshops. One notable programme of theirs was 'The Community and its Writing', with the objective of promoting writing among communities so that they could express their histories and daily lives through the written word (Casa Bello, 2013a). In this way, the government promoted the view of literature as a document of lived experience, accessible to all citizens. As the rise of the testimonial genre in Latin America has proven, facilitating this kind of writing is a valuable antidote to the exclusionary nature of the literary field in earlier periods, affirming that all lives are equally worthy of attention, and giving the oppressed the opportunity to raise awareness of their situation. Nonetheless, following García Canclini (1995), asserting that everyone's stories deserve to be documented is also a way for the government to persuade citizens that they are all equally valued and they each have a role to play in the revolutionary 'Process'. While Casa Bello's classes were restricted to subjects such as poetry, narrative and journalism (Casa Bello, 2013b), CELARG's offering was much more obviously ideological, combining those traditional subjects with courses such as 'Limits of Capitalism and the Paradigm of Development' (CELARG, 2013), encouraging participants to equate writing with political concerns.

\section{Printing and Distribution}

Socialist ideology is more clearly visible in the areas of printing and distribution. At the time of Chávez's death, the state run Imprenta de la cultura (Cultural Press) proclaimed on its now defunct website ' 84 million publications! Made in socialism', while a logo announced, 'The PRESS of the REVOLUTION'. 
Founded in 2007, the press allows state publishers to produce their books at a cost against which private printers and publishers cannot compete. These books are then distributed by the Fundación Distribuidora Venezolana de la Cultura (Venezuelan Foundation for Cultural Distribution), whose mission is to 'distribute and commercialise Venezuelan publications as well as possible in the national and international spheres, in support of the policies of the Venezuelan State in terms of Latin American and Caribbean integration' (Ministerio del Poder Popular para la Cultura, 2007). It is clear from this description that the foundation does not promote and distribute all Venezuelan literature, but only that which fits with the Bolivarian 'Process'. An integral part of the strategy for the distribution of literature in Venezuela is the Fundación Librerías del Sur, a network of bookshops run by the state. In 2006, Librerías del Sur replaced Fundación Kuai Mare, which since 1982 had been working to develop the distribution of Venezuelan books across the country. The mission of the Librerías del Sur is to promote and circulate 'the Venezuelan, Latin American and Caribbean book, through strategies in line with the strengthening of the cultural identity of the sovereign people' (Ministerio del Poder Popular para la Cultura, 2007). While international literary developments had greatly influenced Venezuelan literature during the Punto Fijo period, this statement reasserts the Bolivarian belief that Venezuelan culture and identity must be protected from such influence, presenting the national and the regional as sufficient. With its mention of popular sovereignty, this statement exemplifies how the ideological tenets of the Bolivarian Revolution are reiterated at every opportunity. The effect of Librerías del Sur on public opinions about literature must not be over-estimated, however, as a study of reader behaviour in Venezuela in 2011-2012 found that only 11.3 percent of the population knew of the chain of bookshops, and of those only 40.9 percent had purchased a book there (CENAL, 2013: 58). Moreover, the invisibility of books produced by this state system beyond the country's borders and the Librerías del Sur chain suggests that the Fundación Distribuidora is unconcerned with international distribution, despite stating to the contrary. As has been observed in other 'missions' (España, 2008), what is achieved by cultural policy does not live up to or follow through on what is promised

The final component of the Platform is the Centro Nacional del Libro (National Centre for the Book, CENAL). Founded in 1997 by President Rafael Caldera, CENAL has operated since 2005 as an autonomous institution affiliated with the Ministry of Popular Power for Culture (Ministerio del Poder Popular para la Cultura, 2007). CENAL's duties include running the national book prize; hosting literary festivals - the annual international Filven, plus regional festivals in each state; offering grants to aspiring writers; and creating international links to promote and distribute Venezuelan literature abroad (CENAL, 2011). Despite their stated autonomy, the political positioning of the organisation is clear at first glance at their website, from the socialist red background to the 'News' section which during the 2012 elections was full of support for Chávez. Moreover, Filven has repeatedly come under criticism for its ideological 
bias (Paullier, 2009). While Christian Valles, director of CENAL, denies that divergent voices are not welcomed to the festival, critics including Ana Teresa Torres (2006: 913-914) and Carlos Pacheco (El Nacional, 2013) argue the opposite.

What emerges from this brief account of the different institutions within the Bolivarian literary system is the reliance on oil revenue to subsidise every stage of literary production and distribution. Sesto justifies these subsidies by affirming, 'We are not even making a dent in our oil money through the mass publishing of books and we're making lots of people happy' (Wisotzk, 2006: 41). Bolivarian cultural policy is therefore a clear example of what Sebastian Mazzuca (2013) calls 'rentier populism', using oil revenue to populist ends. Funding short-term benefits that win public support rather than investing in the future is an enduring problem in Venezuela. As early as 1936, Arturo Uslar Pietri famously emphasised the need to 'sembrar el petróleo' (sow oil), to use oil revenue to create a more sustainable economy. He stressed that the oil industry consumes without concerns about sustainability and therefore 'sacrifices the future for the present' (Uslar Pietri, 1936). The populism of the Bolivarian government is reinforced by their discrediting of traditionally elite private publishers, which cannot compete with a State-publisher that has no need to make a profit (Torres, 2006: 921). As observed in other areas, such as the education missions (Ellner, 2011b), the rentier populism of the state benefits the masses at the expense of cultural professionals, reinforcing polarisation.

\section{Protectionist Policies}

As well as the institutions outlined above, the Bolivarian government put in place laws and policies particularly related to currency exchange and exports - designed to promote autochthonous literature and fortify national identity at the expense of access to literature from other countries. Article 38 of the 2005 Law of Culture asserts the duty of the state to protect national culture from international competition as a matter of public interest (Comisión Permanente de Educación..., 2005: 10). In practice, the protectionist nature of Bolivarian cultural policy is evident in the scarcity of foreign fiction in Venezuela. Booksellers Roger Michelena and Rodnei Cáceres claim that books come late or not at all, and many distributors have left Venezuela (Fermín, 2011). Of the more than 70,000 books published in Spain in 2010, only 2,000 became available in Venezuela (Fermín, 2011). This is because, through strict currency controls, the government has made it not financially viable to import books. El País reports that to obtain dollars at a preferential rate, which are required to pay for imports, publishers must first send a list of the titles that they wish to import to the Ministry for Industry and Commerce, who will only approve their request if it can be proven that local authors are not writing on the same topic (Primera, 2009). Such a policy affirms that what is produced nationally is sufficient and disregards the benefits of local ideas entering into 
dialogue with international developments, marking Venezuela as, in Pascale Casanova's (2004) terms, a 'closed literary nation'. These currency regulations also impede the importation of books written by Venezuelan writers but published abroad (Silva-Ferrer, 2014: 136-137), reinforcing the idea that those who leave the country are non-citizens. The result is a marked literary isolation: Venezuelan readers and writers have become increasingly cut off from the new trends and developments in foreign writing. Although the internet is helping somewhat to alleviate literary isolation in recent years, Venezuelan readers can generally only access what is available online for free, as the currency controls limit their ability to purchase anything from abroad online.

\section{Reading and Ideology}

While the Bolivarian government made importing books more difficult, it simultaneously increased distribution of books produced within the country as part of its aim to 'launch a process of democratisation of the book and of reading for the enjoyment and education of all Venezuelan men and women' (Plataforma del Libro..., 2007). This translates to making books more easily available among poorer communities, affirming that reading is not just the preserve of the elite, and that all people are equally deserving of access to books. Widening access to books is undoubtedly positive, counteracting the limiting of reading to an educated elite during the Punto Fijo period (Barrera Linares, 2006). Nonetheless, in practice, making books available to all has also been an attempt to inculcate socialist values, as, the books which were made available in this way are predominantly texts with a socialist message. Even El Quijote was framed in such a way as to be useful for the Revolution. Announcing the plan to give away one million copies of a Venezuelan edition of the book on its $400^{\text {th }}$ anniversary, Chávez proclaimed: 'We are all going to read El Quijoite to nourish ourselves even more with the spirit of a fighter who wanted to right wrongs and fix the world. We are, in a way, followers of Don Quijote' (El País, 2005). From the Bolivarian viewpoint, books are valuable as an inspiration for political action. Moreover, reading is considered a communal activity; 'we are all' (todos nosotros) implies inclusivity and equality. Chávez is one of the people, reading with them, building an 'imagined community' of readers (Anderson, 2006).

The Law of Culture (2005) confirms the state's responsibility for 'strengthening the values of solidarity, justice, honesty, friendship, social responsibility and respect, through the promotion of reading and knowledge' (Comisión Permanente de Educación..., 2005: 7). Consequently, as Edgar Páez, the representantive of the Oficina Nacional del Plan Revolucionario de Lectura [National Office for the Revolutionary Plan for Reading], affirmed, 'Every plan for reading is a plan for ideological development' (Primera, 2009). Launched by Chávez in 2009, the Revolutionary Plan for Reading (PRL) was designed 
to bring about 'a collective act to promote socialism' (Chávez, cited in Primera, 2009). The Ministry of Popular Power for Culture announced that the PRL would 'strengthen identity and a sense of belonging', 'develop a critical reading of reality within communities', 'reaffirm the values leading to the consolidation of the New Man and Woman, as a foundation for the construction of a socialist homeland' and 'incorporate reading as a source of pleasure (Ministerio de Poder Popular para la Cultura, 2009: 15). The PRL suggests a remarkable belief in the power of books, since reading is expected to do so much. Nonetheless, it is paradoxical that they talk of developing critical faculties while recycling concepts such as the New Man and Woman from Cuban rhetoric. To achieve these aims, the PRL facilitated access among poorer communities to those books which 'promote critical and revolutionary thought' (cited in Primera, 2009). Consequently, books such as ¿Por qué soy chavista? [Why Am I Chavista?] by Fransisco Sesto, and Ideas cristianas y otros aportes al debate socialista [Christian Ideas and Other Support for the Socialist Debate], a compilation of speeches by Chávez about how Jesus was a socialist, were stocked in libraries across the country (Primera, 2009). To make way for all this propaganda, other books, including works by Rómulo Gallegos, were removed from public libraries and destroyed with the excuse that they were out-of-date or damaged (Silva-Ferrer, 2014: 122), demonstrating again the aim to remove any trace of the former elites.

Another key element of the PRL was the formation of 'squadrons' of readers, which were sent out into communities to encourage and coordinate group reading. Through such nomenclature, reading programmes become another example of the 'sentimental militarism' that Paula Vásquez Lezama (2013) views as the defining characteristic of Chavism, that is, the constant presence of the military in aspects of civilian life supposedly for the good of the people. The names of these squadrons further elucidate the aims of the plan: Red/Autobiography, Green/Resymbolising, Orange/Relevance-Belonging and Black/Militant Resistance (Ministerio del Poder Popular para la Cultura, 2009: 16). Reading should encourage people to reflect on who they are and foster a sense of belonging to the nation; make people feel that each life story is valued; make a radical break from what came before the Revolution; and reaffirm the myths of military heroes, encouraging people to support the militarised Bolivarian regime. In all instances, reading is instrumentalised, discrediting ideas of writing as art or a source of enjoyment. Despite the flurry of speeches and media attention at the launch of the PRL, however, the programme disappeared after 2009. In this way, the PRL seems consistent with other social programmes which have been seen to tail off after initial promises (España, 2008; Uzcátegui, 2010; Ellner, 2011b).

\section{Conclusions}


This article has shown that through rhetoric, policy and the use of state institutions, the Bolivarian government under Hugo Chávez consistently presented reading and writing as tools to build a national community, spread socialist ideology and garner support for the 'revolutionary Process'. This begins with declarations, such as those of Francisco Sesto in El pueblo es la cultura, about the government's belief in the creative power of the people. The cultural activities he instigated as Minister for Culture - including an extensive programme of writing workshops and the creation of El perro y la rana publishing house are attempts to create a popular counter-hegemony. Promotion of increased access to reading and writing comes at the expenses of literary tradition, literature as a profession and private competition, asserting that only the 'popular' is of value. Many writers, booksellers and literary critics have expressed strong criticism of the instrumentalisation of reading and writing by the Bolivarian government (see Brown, 2016). Similarities can be drawn with the demands for ideological conformity from writers within the Cuban Revolution and the Sandinista Revolution in Nicaragua (Williamson, 2009: 554; Goldman, 1987). Where the Bolivarian Revolution is more radical is in its insistence on the national collective, promoting a plurality of voices without any individual writers as representatives of the revolution. Moreover, a striking antagonism is shown towards professional writers by Chávez and Sesto and reiterated in documents from the 2005 Law of Culture to the presentation text of the Cada día un libro collection, reinforcing the class polarisation that is 'the defining fissure of current Venezuelan politics' (Cannon, 2008: 732). The Venezuelan case is further noteworthy for taking place in an era of globalisation and interconnectedness in cultural production among many Latin American countries (García Canclini, 2002). While countries such as Mexico and Argentina see engagement with global literary markets as a source of income for the country, the Bolivarian government places writing outside of the market and under state control, stressing that the national is sufficient and that the Bolivarian Revolution will provide for all the needs of the people. The increasingly isolationist and populist nature of Bolivarian policies towards reading and writing reflects the ongoing radicalisation observed in other areas of governance, with 2001 and 2007 as key points when the promotion of ideology became stronger, in line with increased optimism following electoral successes in 2000 and 2006 (Ellner, 2011a, Williamson, 2009: 595).

\section{References}

Afanador, A. et al.(2011) 'Observatorio Venezolano de Cultura y Desarrollo: una necesidad en tiempos de cambio'. [WWW document].

URL http://www.casaruibarbosa.gov.br/dados/DOC/palestras/Politicas_Culturais/II_Seminario_Interna cional/FCRB_Ana_Afanador_e_outros_Observatorio_Venezolano_de_Cultura_y_Desarrollo.pdf [accessed 17 April 2017]. 
Anderson, B. (2006) Imagined Communities: Reflections on the Origin and Spread of Nationalism. $2^{\text {nd }}$ ed. Verso: London.

Azócar, R.E. (2013) 'La literatura a través de los premiados: a propósito del Premio Rómulo Gallegos 2013', Apporea, [WWW document]. URL https://www.aporrea.org/actualidad/a157007.html [accessed 16 April 2017].

Barrera Linares, L. (2006) 'Llegaron los ochenta: Confluencia y diversidad en la narrativa finisecular' in C. Pacheco, L. Barrera Linares and B. González Stephan (eds.), Nación y literatura: itinerarios de la palabra escrita en la cultura venezolana. Equinoccio/Fundación Bigott: Caracas, 801-817.

Bencomo, A. (2006) 'El premio Rómulo Gallegos: Avatares de una trayectoria' in C. Pacheco, L. Barrera Linares and B. González Stephan (eds.) Nación y literatura: itinerarios de la palabra escrita en la cultura venezolana. Equinoccio/Fundación Bigott: Caracas, 763-780.

Bermúdez, E. and Sánchez, N. (2009) 'Política, cultura, políticas culturales y consumo cultural en Venezuela'. Cuaderno Venezolano de Sociología, 8(3), 541-576.

Bolaño, R. (2001) 'La paciencia de Bolaño'. Tal Cual. [WWW document]. URL http://www.talcualdigital.com/ediciones/2001/07/09/p23s1.htm [accessed 17 April 2017].

Britto García, L. (2001) 'El Cultarazo'. [WWW document]. URL http://edicionesyo.blogspot.co.uk/2009/08/el-culturazo.html [accessed 17 April 2017].

Brown, K. (2016) The Contested Values of Literature in the Bolivarian Republic of Venezuela (19992015). Unpublished doctoral dissertation, King’s College London, London.

Cannon, B. (2008) 'Class/Race Polarisation in Venezuela and the Electoral Success of Hugo Chávez: A Break with the Past or the Song Remains the Same?', Third World Quarterly, 29(4), 731-748.

Casa Bello. (2013a) 'La Comunidad y su Escritura'. [WWW document]. URL http://casabello.gob.ve/formacion-literaria/la-comunidad-y-su-escritura/ [accessed 6 January 2014 ].

(2013b). 'Talleres'. [WWW document]. URL http://casabello.gob.ve/formacion-literaria/talleres/ [accessed 6 January 2014].

Casanova, P. (2004) World Republic of Letters. Trans. M. B. Debevoise. Harvard University Press: Cambridge, MA.

CELARG. (2013) 'Talleres de creación Fundación Celarg, Septiembre/Diciembre 2013'. [WWW document]. URL http://www.celarg.org.ve/Espanol/talleres\%20de\%20creacion\%20celarg_2013.html [accessed 17 April 2017]. 
CENAL. (2013) 'Estudio del comportamiento lector, acceso al libro y la lectura en Venezuela 20112012'. [WWW document]. URL http://www.distribuidoradellibro.gob.ve/ESTUDIO-CENALCOMPORTAMIENTO-LECTOR.pdf [accessed 20 March 2015].

- $(2011)$ 'Quiénes Somos'.

[WWW document]. URL http://www.cenal.gob.ve/cenal2011/Qui\%C3\%A9nes_Somos [accessed 2 May 2013].

Comisión Permanente de Educación, Cultura, Deportes y Recreación de la Asamblea Nacional de Venezuela. (2005) 'Ley Orgánica de la Cultura’. Asamblea Nacional de Venezuela, Caracas.

Congreso de la República de Venezuela (1975). 'Gaceta oficial de la República de Venezuela. Número 1.768 Extraordinario. Ley del Consejo Nacional de la Cultura'. Congreso de la República de Venezuela, Caracas.

Corrales, J. and Penfold, M. (2011). Dragon in the Tropics: Hugo Chávez and the Political Economy of Revolution in Venezuela. Brookings Institution Press: Washington, DC.

Davisson, B. (2013) 'The Narrative is (Not) the Territory: Luis Cardoza y Aragón's Guatemala, las líneas de su mano and the Guatemalan Revolution', A Contra Corriente, 10(2), 102-135.

El Nacional. (2013). 'Carlos Pacheco: Los festivales literarios nos humanizan y nos ayudan a dialogar'. El Nacional. [WWW document]. URL http://www.el-nacional.com/noticias/historico/carlospacheco-los-festivales-literarios-nos-humanizan-nos-ayudan-dialogar 165801 [accessed 05 March 2018].

El País. (2005). 'Hugo Chávez regalará un millón de ejemplares del 'Quijote'. El País. [WWW document]. URL http://elpais.com/diario/2005/04/18/cultura/1113775204_850215.html [accessed 17 April 2017].

El Perro y la Rana. (2015). 'Editorial Escuela El perro y la rana: "Lo nuestro es Leer"'. [WWW document]. URL http://www.elperroylarana.gob.ve/noticias-fepr/287-editorial-escuela-el-perro-yla-rana-lo-nuestro-es-leer.html [accessed 10 August 2015].

Ellner, S. (2011a) 'Does the Process of Change in Venezuela Resemble a "Permanent Revolution"?'. Dialectical Anthropology, 35, 249-253.

- (2011b) 'Venezuela's Social-Based Democratic Model: Innovations and Limitations'. Journal of Latin American Studies, 43(3), 421-449.

España, L.P. (2008) 'The Social Policy of the Bolivarian Revolution', ReVista: Harvard Review of Latin America. [WWW document]. URL http://revista.drclas.harvard.edu/book/social-policy-bolivarianrevolution [accessed 16 April 2017].

Farrell, M.L. (2011) A 'Revolution of Consciousness': Redefining Venezuelan National Identities through Cinema. Unpublished doctoral dissertation, Georgetown University, Washington DC. 
Fermín, D. (2011) '95\% de los libros del mundo no llegan al país’, El Universal. [WWW document]. URL http://www.eluniversal.com/2011/02/08/til_art_95-de-los-libros-de_2185546.shtml [accessed 17 April 2017].

García Canclini, N. (2002) Latinoamericanos buscando lugar en este siglo. Paidós: Buenos Aires.

(1995) Hybrid Cultures: Strategies for Entering and Leaving Modernity. Trans. C. L. Chiappari and S. L. López. University of Minnesota Press: Minneapolis.

Goldman, F. (1987) 'Poetry and Power in Nicaragua', New York Times, [WWW document]. URL http://www.nytimes.com/1987/03/29/magazine/poetry-and-power-in-nicaragua.html [accessed 10 February 2018].

Gott, R. (2000). In the Shadow of the Liberator: Hugo Chávez and the Transformation of Venezuela. Verso: London.

Grases González, P. (1995) 'Fundación La Casa de Bello, en Caracas’ in M. Seco and G. Salvador (eds.) La lengua española, hoy. Fundación Juan March: Madrid, 311-320.

Guerrero, G. (2005) 'Réquiem por un galardón', El País, [WWW document]. URL http://elpais.com/diario/2005/07/15/cultura/1121378402_850215.html [accessed 16 April 2017].

Hawkins, K.A. (2010). Venezuela's Chavismo and Populism in Comparative Perspective. Cambridge University Press: Cambridge.

Hawkins, K.A., Rosas, G. and Johnson, M.E. (2011) 'The Misiones of the Chávez Government', in D. Smilde and D. Hellinger (eds.) Venezuela's Bolivarian Democracy: Participation, Politics, and Culture under Chávez. Duke University Press: Durham, NC, 188-220.

Kozak Rovero, G. (2007) 'Políticas culturales y hegemonía en la revolución bolivariana: "ética y estética socialistas'. Estudios, 14(28), 101-121.

Letralia (2008) 'Será liquidado el Consejo Nacional de la Cultura de Venezuela'. Letralia. [WWW document]. URL http://www.letralia.com/187/0512conac.htm [accessed 23 December 2013].

López Maya, M. and Lander, L.E. (2011). 'Participatory Democracy in Venezuela: Origins, Ideas, and Implementation' in D. Smilde and D. Hellinger (eds.) Venezuela's Bolivarian Democracy: Participation, Politics, and Culture under Chávez. Duke University Press: Durham, NC, 58-79.

Márquez Rodríguez, A. (1999). 'La función de la editorial Monte Ávila en el proceso de la literatura venezolana', in K. Kohut (ed.) Literatura venezolana hoy: Historia nacional y presente urbano. Verveut: Frankfurt, 85-94.

Mazzuca, S.L. (2013) 'The Rise of Rentier Populism'. Journal of Democracy, 24(2), 108-122.

Méndez, M.G. (2013) 'Un mundo perdido', Revista Arcadia. [WWW document]. URL http://www.revistaarcadia.com/impresa/reportaje/articulo/un-mundo-perdido/32469 [accessed 17 April 2017]. 
Ministerio de Comunicación e Información. (2005). 'Misión Cultura'. [WWW document]. URL http://www.minci.gob.ve/wp-content/uploads/downloads/2013/02/misioncultura.pdf [accessed 10 February 2018].

Ministerio del Poder Popular para la Cultura. (2009) 'Procesos del Libro y Plan Revolucionario de Lectura en Venezuela'. Ministerio del Poder Popular para la Cultura, Caracas.

- (2007) 'Plataformas Culturales: Libro y Lectura'. [WWW document]. URL http://www.mincultura.gob.ve/index.php/home/plataformas-culturales [accessed 20 April 2013].

Monte Ávila. (2014) 'Quiénes somos'. [WWW document]. URL http://www.monteavila.gob.ve/2014/quienes.php [accessed 07 August 2015].

Pau, A. (2005) 'Sobre el Premio Rómulo Gallegos', El País, http://elpais.com/diario/2005/07/19/opinion/1121724005_850215.html [accessed 16 April 2017].

Paullier, J. (2011) 'Venezuela: Una feria del libro en revolución', BBC Mundo. [WWW document]. URL [WWW document]. http://www.bbc.co.uk/mundo/noticias/2011/03/110325_venezuela_feria_libro_filven_revolucion_ ideologia_jp.shtml [accessed 17 April 2017].

Plataforma del Libro y la Lectura del Ministerio del Poder Popular para la Cultura. (2007) 'Manifiesto sobre la gestión cultural a favor del libro y la lectura'. Ministerio del Poder Popular para la Cultura., Caracas.

Prensa-CONAC. (2005) 'Certamen Mayor de las Artes y las Letras en su Capítulo Literatura', Aporrea. [WWW document]. URL http://www.aporrea.org/actualidad/n16615.html [accessed 17 April 2017].

Primera, M. (2009) 'Chávez lanza su revolución cultural', El País. [WWW document]. URL http://elpais.com/diario/2009/05/14/internacional/1242252001_850215.html [accessed 17 April 2017].

Roberts, K. (2004). 'Social Polarization and the Populist Resurgence in Venezuela' in S. Ellner and D. Hellinger (eds.) Venezuelan Politics in the Chávez Era: Class, Polarization, and Conflict. Lynne Rienner: Boulder, CO, 55-72.

Rodner, V.L. (2014) The Art Machine: The Case of the Venezuelan Art Market. Unpublished doctoral dissertation, King's College London, London.

Rosa, I. (2005) 'Convicciones íntimas', El País, [WWW document]. URL http://elpais.com/diario/2005/07/18/cultura/1121637603_850215.html [accessed 16 April 2017].

Sesto, F. (2006) ¿Por qué soy chavista? Razones de una Revolución. Ocean Sur: Caracas.

Silva-Ferrer, M. (2014) El cuerpo dócil de la cultura: Poder, cultura y comunicación en la Venezuela de Chávez. Iberoamericana: Madrid. 
Smilde, D. (2011) 'Participation, Politics, and Culture: Emerging Fragments of Venezuela's Bolivarian Democracy', in D. Smilde and D. Hellinger (eds.) Venezuela's Bolivarian Democracy. Duke University Press: Durham, NC, 1-27.

TeleSUR (2013) 'No puede haber Revolución sin cultura: Hugo Chávez', TeleSUR, [WWW document]. URL http://videos.telesurtv.net/video/123407/no-puede-haber-revolucion-sin-cultura-hugo-chavez [accessed 16 April 2017].

Torres, A. T. (2006) 'Cuando la literatura venezolana entró en el siglo XXI' in C. Pacheco, L. Barrera Linares and B. González Stephan (eds.), Nación y literatura: itinerarios de la palabra escrita en la cultura venezolana. Equinoccio/Fundación Bigott: Caracas, 911-925.

Uslar Pietri, A. [1936] (2016). 'Sembrar el petróleo'. [WWW document]. URL https://www.elcambur.com.ve/opinion/sembrar-el-petroleo-por-arturo-uslar-pietri [accessed 17 April 2017].

Uzcátegui, R. (2010) La Revolución como espectáculo: una crítica anarquista al gobierno bolivariano. El Libertario: Caracas.

Vásquez Lezama, P. (2014) Le chavisme: Un militarisme compassionnel. Maison des sciences de l'homme: Paris.

Williamson, E. (2009) The Penguin History of Latin America. Revised edition. Penguin : London.

Wisotzk, R. (2006) El pueblo es la cultura: Conversación con Farruco Sesto, Ministro de la Cultura. El perro y la rana: Caracas. 